Karakteristik Sebaran Besar Butir Endapan Pantai Pulau Sumba, Nusa Tenggara Timur Berdasarkan Data Ukuran Butir dan Geokimia

\title{
Characteristics of Grain Size Distribution on Beaches Sediment of Sumba Island, Nusa Tenggara Timur Based on Grainsize and Geochemical Data
}

\author{
Septriono Hari Nugroho dan Purna Sulastya Putra ${ }^{2}$ \\ ${ }^{1}$ Pusat Penelitian Laut Dalam LIPI, Jalan Y. Syaranamual, Guru-guru, Poka - Ambon \\ ${ }^{2}$ Pusat Penelitian Geoteknologi LIPI, Jalan Sangkuriang, Bandung 40135 \\ e-mail: sept006@lipi.go.id \\ Naskah diterima : 31 Juli 2018, Revisi terakhir : 28 Juli 2019 Disetujui : 29 Juli 2019, Online : 7 Agustus 2019 \\ DOI: http://dx.doi.org/10.33332/jgsm.20.3.153-164
}

\begin{abstract}
Abstrak- Studi karakteristik endapan pantai dilakukan di tiga lokasi di pantai Pulau Sumba, Nusa Tenggara Timur. Penelitian tersebut merupakan bagian dari Ekspedisi Widya Nusantara yang dilakukan menggunakan Kapal Riset Baruna Jaya VIII. Penelitian ini bertujuan untuk mengetahui karakteristik endapan pantai melalui pengamatan ukuran butir dengan menggunakan pendekatan analisis tren ukuran butir (Grain Size Trend Analysis yang biasa disingkat GSTA) dan analisis geokimia. Sebanyak 36 sampel diambil pada masingmasing pantai yang mewakili daerah pasang maksimum, transisi dan surut maksimum sepanjang pantai. Analisis besar butir dilakukan menggunakan alat Malvern Mastersizer 2000 yang diolah dengan perangkat lunak Gradistat 4.0. Analisis geokimia dilakukan menggunakan $X$-ray fluorescence spectrometry (XRF). Sebaran endapan pantai di dominasi oleh pasir sedang - pasir kasar dengan kandungan unsur geokimia ( $\mathrm{Ca}, \mathrm{Sr}, \mathrm{Fe}, \mathrm{K}$, dan $\mathrm{Ti}$ ) yang berbeda-beda. Kondisi pantai yang berhadapan dengan Samudra Hindia (B1) memiliki karakteristik yang berbeda dengan pantai yang berhadapan dengan Selat Sumba (B5 dan B7). Analisis GSTA menunjukkan sedimen pantai Laboya lebih halus dibandingkan pantai Waikelo dan Melolo. Kandungan unsur geokimia di pantai Laboya menujukkan perbedaan dibandingkan kedua pantai lainnya. Hal tersebut menunjukkan adanya perbedaan pula sumber batuan asal dan komposisi pada ketiga pantai. Suplai endapan pantai di ketiga pantai tersebut diendapkan secara menggelinding dan dipengaruhi oleh proses gelombang dan sungai.
\end{abstract}

Katakunci: Karakteristik, sedimen, ukuran butir, geokimia, $\mathrm{XRF}$, endapan pantai.

\begin{abstract}
Study of beaches sediment characteristics were conducted on three beaches on Sumba Island, East Nusa Tenggara.The research is a part of Widya Nusantara Expedition which conducted by using Research Vessel of Baruna Jaya VIII. The aim of this study is to determine the characteristics of coastal deposits through the observation of grain size by using the grain size trend analysis approach (Grain Size Trend Analysis, commonly abbreviated as GSTA) and geochemical analysis. A total of 36 samples were taken on each coast representing high tide, transition and low tide along the coast. A grain size analysis was performed using a Malvern Mastersizer 2000 that was processed with Gradistat 4.0 software. Geochemical analysis was carried out using X-ray fluorescence spectrometry (XRF). The distribution of beach sediments is dominated by moderate sand - coarse sand and differences on content of geochemical elements ( $\mathrm{Ca}, \mathrm{Sr}, \mathrm{Fe}, \mathrm{K}$, and $\mathrm{Ti}$ ). The coastal conditions that are connected to the Indian Ocean (B1) have different characteristics from the beach that connected to the Sumba strait (B5 and B7). GSTA analysis showed sediment of Laboya Beach finer than sediment on Waikelo and Melolo Beach. Geochemical elements on Laboya Beach indicates different values than others. It indicates there are differences in the provenance and composition of sediment on the all three beaches. The supply of coastal deposits on these three beaches is influenced by the mechanism of precipitation of the walls and the processes of waves and rivers.
\end{abstract}

Keywords: distribution, sediment, grainsize, geochemical, $X R F$, beach sediment. 


\section{PENDAHULUAN}

Studi karakteristik tekstural endapan pantai dapat digunakan untuk membedakan lingkungan pengendapan sedimen. Endapan pantai pada umumnya dipengaruhi oleh energi gelombang dan morfologi pantai. Karakteristik ukuran butir di daerah pasangsurut dapat mengalami perubahan seiring dengan proses transportasi sedimen yang terjadi. Arus pasang surut air laut mempunyai peranan penting dalam perubahan karakteristik tekstural endapan pantai. Analisis statistik endapan pantai sangat berhubungan erat dengan lingkungan pengendapan sedimen. Rataan (mean), sortasi dan skewness adalah parameter yang sering digunakan untuk menjelaskan kondisi sedimen (Friedman, 1961; Carranza-Edwards, 2001). Komposisi sedimen dan teksturnya tergantung pada gelombang, angin dan longshore current dan komposisi asal sedimen (Komar, 1976). Analisis statistik ukuran butir digunakan untuk membedakan energi pengendapan baik energi sedang maupun tinggi (Nordstrom, 1977).

Penelitian ini dilakukan di tiga lokasi pantai berbeda di Sumba, Nusa Tenggara Timur (NTT), yaitu Pantai Laboya (B1), Pantai Melolo (B5) dan Pantai Waikelo (B7). Ketiga pantai tersebut memiliki karakter geografi berbeda, yaitu berhadapan langsung dengan Samudera Indonesia dan juga berhadapan dengan pulau-pulau sekitar (Sumbawa dan Flores). Secara geologi, lokasi tersebut sangat menarik, namun data penelitian terkait distribusi ukuran butir di lokasi tersebut masih sangat jarang. Penelitian ini difokuskan untuk membandingkan karakteristik distribusi sedimen tiga pantai di Pulau Sumba melalui pengamatan ukuran butir dan studi bahan sumber (provenance) dengan menggunakan pendekatan analisis tren ukuran butir (GSTA) dan analisis geokimia. GSTA biasa digunakan untuk membedakan karakter fisik dan tekstural yang berfungsi untuk mengetahui transportasi dan pengendapan sedimen (Nugroho \& Putra 2017). Beberapa penelitian tentang distribusi sedimen memberikan informasi sumber sedimen, transportasi dan pengendapan sedimen (Angusamy \& Rajamanickam 2006; Nugroho 2013; Nugroho \& Basit 2014; Nugroho \& Putra 2017). Parameter ukuran butir tersebut digunakan baik di lingkungan pengendapan modern maupan masa lalu (antara lain Malvarez et al., 2001; Ramamohanarao drr., 2003; Suresh drr., 2008; Ramanathan et al., 2009; Anithamary et al., 2011). Analisis geokimia sedimen pantai bertujuan untuk menentukan komposisi unsur kimia dari suatu material yang dapat dimanfaatkan dalam penelusuran bahan sumber dan keterkaitan dengan satuan lain pada suatu wilayah (Irzon, 2018). Brouwer (2010) menyatakan bahwa XRF merupakan analisis yang sangat berguna untuk mendukung data kandungan unsur kimia suatu material. Analisis tersebut digunakan untuk mendukung interpretasi sumber atau asal sedimen tersebut. Pendekatan geokimia sudah banyak digunakan untuk penelitian baik penelitian oseanografi, paleoklimat, perubahan lingkungan dan juga paleotsunami. Unsur yang dapat direkam oleh analisis XRF antara lain unsur utama yaitu $\mathrm{Si}, \mathrm{Ti}, \mathrm{Al}, \mathrm{Fe}, \mathrm{Mn}, \mathrm{Mg}, \mathrm{Ca}, \mathrm{Na}, \mathrm{K}$, P. Adapun unsur sekunder adalah $\mathrm{Ba}, \mathrm{Ce}, \mathrm{Co}, \mathrm{Cr}, \mathrm{Cu}, \mathrm{Ga}, \mathrm{La}, \mathrm{Nb}$, $\mathrm{Ni}, \mathrm{Rb}, \mathrm{Sc}, \mathrm{Sr}, \mathrm{Rh}, \mathrm{U}, \mathrm{V}, \mathrm{Y}, \mathrm{Zr}$ dan Zn (Gosseau, 2009). Namun menurut Rothwell \& Croudace (2015) unsurunsur yang umum digunakan sebagai penjejak untuk merekonstruksi kondisi lingkungan tertentu adalah Kalsium (Ca), Besi (Ferrum/Fe), Strontium (Sr), Kalium(K), dan Titanium (Ti).

Dalam beberapa dekade terakhir,beberapa peneliti telah melakukan studi tentang tekstur endapan pantai dan geokimia baik di Indonesia maupun di luar negeri, seperti di pantai timur dan barat India (Rao, et al., 2005; Angusamy \& Rajamanickam 2006 \& 2007; Suresh et al., 2008; Ramanathan et al., 2009; Anithamary et al., 2011; Rajganapathi et al., 2012). Menurut penelitian yang dilakukan mereka, endapan pantai mempunyai peranan penting dalam sejarah pengendapan endapan pantai. Proses pengendapan endapan pantai bersifat dinamis dan dikontrol oleh kondisi geologi dan iklim dan memberikan penjelasan bahwa sedimen terbentuk akibat erosi oleh arus pasang-surut. Di Indonesia bagian barat dan Indonesia bagian timur juga sudah pernah ada yang melakukan penelitian tersebut (Nugroho, 2013; Nugroho \& Putra, 2017; Zuraida dkk., 2017; Irzon, 2018). Penelitian yang dilakukan Nugroho (2013) hanya terbatas pada identifikasi dan distribusi sedimen, tidak membahas proses transportasi dan pengendapan sedimen. Nugroho \& Putra (2017) melakukan studi endapan pantai di Pantai Waikelo yang terletak di bagian utara Pulau Sumba. Dalam studinya, Nugroho \& Putra menjelaskan bahwa kelimpahan pasir kasar hingga pasir sedang menunjukkan secara umum proses pengendapan sedimen di sepanjang pantai Waikelo diendapkan pada energi sedang hingga rendah. Penelitian yang dilakukan Zuraida dkk. (2017) bertujuan untuk mengetahui karakteristik sedimen pantai dan dasar laut Teluk Papela, Rote, NTT. Dalam studinya, selain membahas terkait sedimentology juga membahas aspek mineralogi dan geokimia. Keterdapatan $\mathrm{Sr}$ yang melimpah berhubungan dengan kandungan organisme pembentuk cangkang, sedangkan kandungan I dipengaruhi oleh kandungan bahan 
organik. Keterdapatan Pu dalam sedimen Teluk Papela diperkirakan merupakan hasil aktivitas manusia yang terserap dalam cangkang dan terakumulasi dalam sedimen pantai dan dasar laut. Irzon (2018) melakukan penelitian yang bertujuan untuk mengetahui kadar geokimia pasir pantai di pesisir selatan Kulonprogo, DIY. Berdasarkan penelitiannya dikatakan bahwa sedimen pantai memiliki derajat maturitas rendah dan terbentuk pada lingkungan kering berdasarkan data geokimia.

Studi terkait sumber batuan asal (provenance) dan komposisi sedimen berbasis GSTA dan geokimia yang diterapkan pada tiga endapan pantai yang berbeda di Pulau Sumba (Gambar 1), yaitu di sebelah utara bagian barat (Pantai Waikelo) dan bagian timur (Pantai Melolo) serta di sebelah Selatan (Pantai Laboya) belum pernah dilakukan. Penelitian ini bertujuan untuk memahami karakteristik sedimen dan hubungannya terhadap satuan-satuan batuan lain di sekitarnya. Harapannya data tersebut dapat digunakan untuk menilai prospeksi terhadap bahan galian ekonomis pada suatu wilayah.

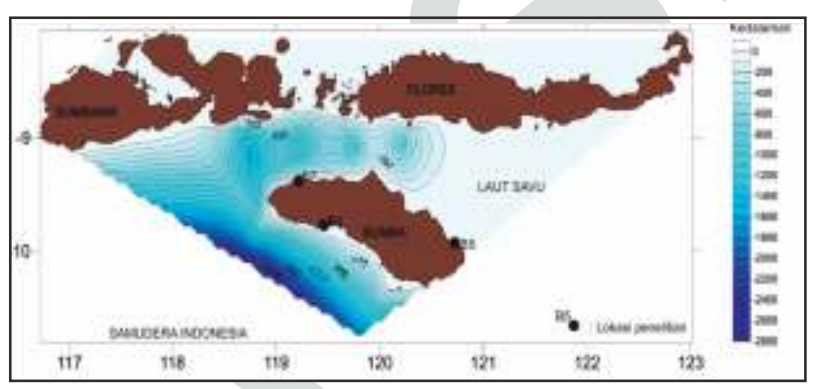

Gambar 1. Peta lokasi pengambilan sampel ekspedisi Widya Nusantara 2016. Tanda bulat hitam bertuliskan B1, B5 dan B7 adalah lokasi pengambilan sampel endapan pantai.

\section{METODE}

Penelitian ini merupakan bagian dari Ekspedisi Widya Nusantara 2016 yang diselenggarakan oleh Pusat Penelitian Oseanografi LIPI di Perairan Sumba dan sekitarnya. Pengambilan sampel di lakukan pada tanggal 4 - 26 Agustus 2016. Sampel diperoleh dari endapan pantai di tiga lokasi pantai yang berbeda di Pulau Sumba, yaitu Pantai Waikelo (B7), Laboya (B1), dan Melolo (B5) (Gambar 1). Perbedaan kondisi geografi yang berbeda dijadikan sebagai alasan dalam penentuan lokasi. Pantai Laboya (B1) berbatasan dengan Samudera Indonesia (B1), berbatasan dengan Selat Sumba dan berhadapan pulau-pulau sekitar (Pulau Flores dan Pulau Sumbawa) (B7) serta berbatasan dengan Laut Savu (B5). Sampel pada masing-masing pantai diambil mewakili daerah pasang maksimum, transisi dan surut maksimum sepanjang pantai dengan interval kurang lebih $50 \mathrm{~m}$.

Analisis besar butir dilakukan menggunakan alat Malvern Mastersizer 2000 di Laboratorium Sedimentologi, Pusat Penelitian Geoteknologi LIPI, Bandung. Alat tersebut mengukur besar butir dengan kisaran butir 0,02 $\mu \mathrm{m}$ hingga $2000 \mu \mathrm{m}$. Masing-masing sampel diperlukan sekitar 2 gr untuk proses pemisahan ukuran butir. Selanjutnya hasil pengukuran ukuran butir diolah menggunakan perangkat lunak Gradistat v.4.0 (Blott \& Pye, 2001) untuk menghasilkan parameter statistik berupa mean, skewness, kurtosis dan sortasi dengan menggunakan metode geometri Folk \& Ward (1957). Adapun perhitungan dan klasifikasi parameter statistik yang digunakan dalam penelitian ini seperti yang tercantum pada Tabel 1. Parameter tersebut digunakan sebagai pendekatan untuk menentukan sistem transportasi sedimen (Folk \& Ward, 1957). Putra \& Nugroho (2017) dalam papernya menjelaskan bahwa masing-masing parameter tersebut dapat menceritakan kondisi sedimen pada saat mengalami transportasi dan pengendapan. Mekanisme transportasi sedimen dapat diketahui dengan membuat diagram CM (Passega, 1964; Passega \& Byramjee, 1969; Visher, 1969). C merupakan nilai persentil pertama (D90) sedangkan $\mathrm{M}$ adalah nilai median, keduanya diperoleh dari perhitungan statistik menggunakan Gradistat 4.0 dalam satuan micron $(\mu \mathrm{m})$. Selanjutnya untuk mengetahui proses dan laju pengendapan sedimen sepanjang pantai dilakukan analisis Stewart (Stewart, 1958). Diagram Stewart membandingkan nilai median dan sortasi dalam satuan phi.

Tabel 1. Rumus perhitungan dan klasifikasi parameter statistik yang digunakan dalam penelitian ini (Folk \& Ward, 1957)

\begin{tabular}{|c|c|c|c|c|c|}
\hline Rerata & Sortasi & \multicolumn{2}{|c|}{ Skewness } & \multicolumn{2}{|c|}{ Kurtosis } \\
\hline$x_{1}=\frac{5 / 6}{100}$ & 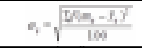 & \multicolumn{2}{|c|}{ 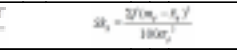 } & \multicolumn{2}{|c|}{$x,=\frac{x+20,-5 y}{1000}$} \\
\hline \multicolumn{2}{|c|}{ Sortasi $\left(\sigma_{\varnothing}\right)$} & \multicolumn{2}{|c|}{ Skewness $\left(S k_{\phi}\right)$} & \multicolumn{2}{|c|}{ Kurtosis $\left(K_{\phi}\right)$} \\
\hline Sortasi sangat baik & $<0.35$ & y fine skewed & $>+1.30$ & Very platykurtic & $<1.70$ \\
\hline Sortasi baik & $0.35-0.50$ & e skewed & $+0.43-+1.30$ & Platykurtic & $1.70-2.55$ \\
\hline Sortasi cukup baik & $0.50-0.70$ & umetrical & $-0.43-+0.43$ & Mesokurtic & $2.55-3.70$ \\
\hline Sortasi sedang & $0.70-1.00$ & arse skewed & $-0.43--1.30$ & Leptokurtic & $3.70-7.40$ \\
\hline Sortasi buruk & $1.00-2.00$ & y coarse skewed & $<-1.30$ & Very leptokurtic & $>7.40$ \\
\hline Sortasi sangat buruk & $2.00-4.00$ & & & & \\
\hline Sortasi terlalu buruk & $>4.00$ & & & & \\
\hline
\end{tabular}

Analisis geokimia dilakukan menggunakan alat X-ray fluorescence (XRF) Analyzer Thermo Scientific di Laboratorium Sedimentologi, Pusat Penelitian Geoteknologi LIPI, Bandung. Hasil analisis diperoleh dalam part per million (ppm). Hasil pengukuran kemudian diolah dengan menggunakan perangkat lunak Excel dan kemudian dibuat peta-nya untuk melihat distribusi secara lateral dengan menggunakan bantuan perangkat lunak Surfer 15.0. Unsur yang digunakan dalam penelitian ini adalah $\mathrm{Ca}, \mathrm{Fe}, \mathrm{Sr}, \mathrm{K}$ dan $\mathrm{Ti}$ (Rothwell \& Croudace, 2015). 


\section{HASIL PENELITIAN}

\section{Parameter statistik endapan pantai}

Hasil perhitungan statistik masing-masing pantai disajikan dalam bentuk tabel dan grafik bivariate, endapan pantai Laboya (Tabel 2 dan Gambar 2), endapan pantai Melolo (Tabel 3 dan Gambar 3), dan endapan pantai Waikelo (Tabel 4 dan Gambar 4). Hasil analisis digunakan untuk membedakan lingkungan pengendapan sedimen yang menggambarkan perbedaan mekanisme transportasi dan pengendapan masing-masing pantai.

Adanya perbedaan karakteristik pada masing-masing pantai terjadi baik pada daerah pasang maksimum, transisi maupun surut maksimum ditunjukkan pada gambar 2, 3 dan 4. Gambar 2a menggambarkan hubungan antara mean dan sortasi di daerah pasang maksimum, transisi dan surut maksimum di Pantai Laboya (B1). Gambar tersebut menunjukkan bahwa pada Pantai Laboya (B1) baik di daerah pasang maksimum, transisi maupun surut maksimum didominasi oleh pasir sedang dengan sortasi sedang yang ditunjukkan dengan nilai sortasi 0,474 hingga 0,663 (Tabel 2). Berbeda dengan Pantai Melolo (Gambar 3a) dan Pantai Waikelo (Nugroho \& Putra, 2017; Gambar 4a) yang menunjukkan sampel di daerah pasang maksimum dan transisi didominasi oleh pasir sedang dengan sortasi sedang yaitu rata-rata 0,771 hingga 0,888 (Tabel 3 dan 4). Pada daerah surut maksimum didominasi oleh pasir kasar dengan sortasi sedang yang ditunjukkan dengan nilai sortasi 0,868 hingga 0,990 (Tabel 3 dan 4).

Gambar 2b, 3b dan 4b menggambarkan hubungan mean dan skewness. Gambar tersebut menjelaskan bahwa dominasi pasir kasar hingga pasir sedang pada masingmasing pantai menunjukkan nilai kemencengan (skewness) yang simetris (symmetrical) yang bernilai rata-rata -0,130 hingga 0,340 (Tabel 1,2 dan 3). Namun, pada pantai Melolo dan Waikelo (Nugroho \& Putra, 2017; Gambar 3b dan 4b) beberapa sampel menunjukkan nilai skewness di atas 0,43 (fine skewed).

Gambar 2c, 3c dan 4c menggambarkan hubungan mean dan kurtosis yang mengindikasikan sebagian besar keseluruhan daerah di masing-masing pantai memiliki nilai kurtosis rata-rata sebesar 0,970 - 1,720 (Tabel 2, 3 dan 4) yang termasuk dalam kelompok very platykurtic. Gambar 2d, 3d dan 4d menunjukkan adanya hubungan sortasi dan skewness pada masing-masing daerah di sepanjang pantai yang berbeda. Pada Pantai Laboya secara umum didominasi oleh pasir sedang yang memiliki sortasi cukup baik dengan nilai skewness simetris (Gambar 2d), sedangkan pada Pantai Melolo dan Waikelo (Nugroho \& Putra, 2017; Gambar 3d dan $4 d)$ didominasi oleh pasir kasar hingga sedang dengan sortasi sedang dengan nilai skewness simetris.

Tabel 2. Hasil parameter statistik ukuran butir pada endapan Pantai Laboya (B1)

\begin{tabular}{lcccc}
\hline & Mean & Sortasi & Skewness & Kurtosis \\
\hline Pasang Maks & & & & \\
maks & 1.659 & 0.663 & 0.053 & 1.149 \\
min & 1.344 & 0.474 & -0.164 & 0.941 \\
rata-rata & 1.468 & 0.574 & -0.056 & 1.075 \\
\hline Transisi & & & & \\
maks & 1.664 & 0.732 & 0.185 & 1.106 \\
min & 1.081 & 0.497 & -0.120 & 0.949 \\
rata-rata & 1.363 & 0.601 & -0.037 & 1.042 \\
\hline Surut maks & & & & \\
maks & 1.920 & 0.680 & 0.148 & 1.034 \\
min & 0.818 & 0.439 & -0.105 & 0.953 \\
rata-rata & 1.181 & 0.567 & 0.001 & 0.991 \\
\hline
\end{tabular}

Tabel 3. Hasil parameter statistik ukuran butir pada endapan Pantai Melolo (B5)

\begin{tabular}{lcccc}
\hline & Mean & Sortasi & Skewness & Kurtosis \\
\hline Pasang Maks & & & & \\
maks & 2.053 & 1.020 & -0.017 & 1.275 \\
min & 1.227 & 0.653 & -0.192 & 0.917 \\
rata-rata & 1.611 & 0.799 & -0.130 & 1.099 \\
\hline Transisi & & & & \\
maks & 0.889 & 1.291 & 0.585 & 3.063 \\
min & 0.273 & 0.667 & -0.002 & 0.874 \\
rata-rata & 0.530 & 0.880 & 0.306 & 1.720 \\
\hline Surut maks & & & & \\
maks & 1.787 & 1.246 & 0.375 & 1.712 \\
min & 0.605 & 0.768 & -0.221 & 0.772 \\
rata-rata & 1.141 & 0.990 & 0.022 & 1.133 \\
\hline
\end{tabular}

Tabel 4. Hasil parameter statistik ukuran butir pada endapan Pantai Waikelo (B7; Nugroho \& Putra, 2007)

\begin{tabular}{lrrrr}
\hline & Mean & Sortasi & Skewness & Kurtosis \\
\hline Pasang Maks & & & & \\
maks & 1.974 & 1.084 & 0.103 & 1.123 \\
min & 0.924 & 0.425 & -0.211 & 0.678 \\
rata-rata & 1.450 & 0.771 & -0.020 & 0.970 \\
\hline Transisi & & & & \\
maks & 1.223 & 1.529 & 0.665 & 1.904 \\
min & 0.052 & 0.431 & 0.183 & 0.891 \\
rata-rata & 0.496 & 0.753 & 0.340 & 1.195 \\
\hline Surut maks & & & & \\
maks & 2.022 & 1.154 & 0.541 & 1.160 \\
min & 0.391 & 0.511 & -0.177 & 0.748 \\
rata-rata & 1.274 & 0.868 & 0.090 & 0.924 \\
\hline
\end{tabular}




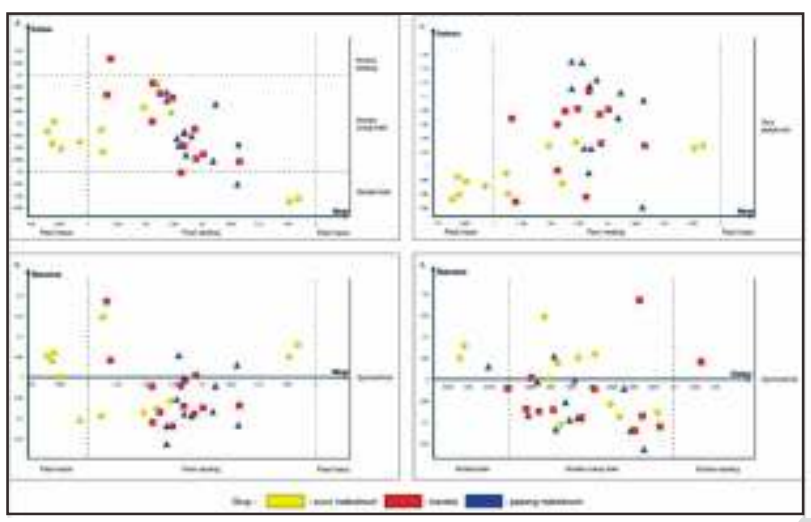

Gambar 2. Grafik bivariate pada endapan Pantai Laboya (B1) yang menggambarkan: a. hubungan mean dan sortasi; b. hubungan mean dan skewness; c. hubungan mean dan kurtosis; $\mathrm{d}$. hubungan sortasi dan skewness.

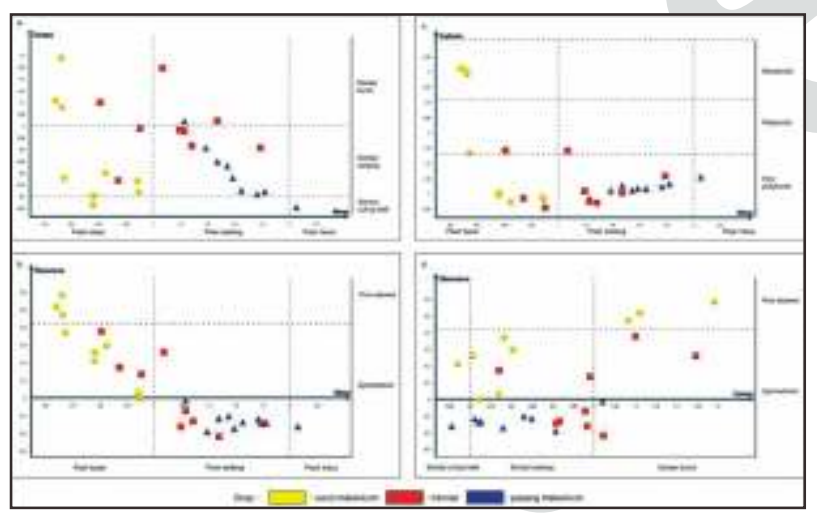

Gambar 3. Grafik bivariate pada endapan Pantai Melolo (B5) yang menggambarkan: a. hubungan mean dan sortasi; b. hubungan mean dan skewness; c. hubungan mean dan kurtosis; $\mathrm{d}$. hubungan sortasi dan skewness.

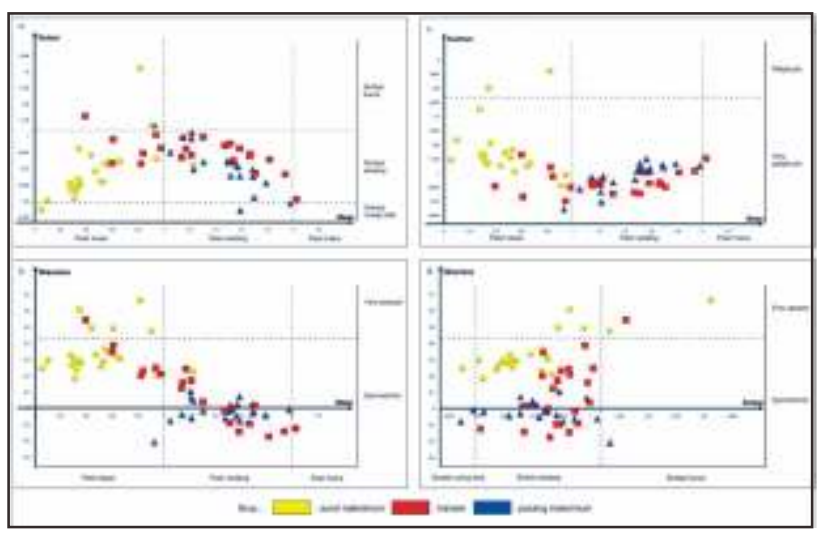

Gambar 4. Grafik bivariate pada endapan pantai Waikelo (B7) yang menggambarkan: a. hubungan mean dan sortasi; b. hubungan mean dan skewness; c. hubungan mean dan kurtosis; d. hubungan sortasi dan skewness (Nugroho \& Putra, 2007 dengan modifikasi)

\section{Sebaran Sedimen Endapan Pantai}

Secara umum, sebaran sedimen di sepanjang pantai di Pulau Sumba dibedakan berdasarkan lokasi pengambilan sampel yang mewakili daerah pasang maksimum, transisi dan surut maksimum (Gambar 2). Sebaran sedimen di daerah pasang maksimum pada umumnya didominasi oleh pasir sedang, sedangkan daerah surut maksimum didominasi oleh pasir kasar. Pencampuran jenis sedimen pasir halus, pasir sedang dan pasir kasar ditemukan pada daerah transisi. Namun secara spesifik masing-masing pantai memiliki karakteristik jenis sedimen yang berbeda (Tabel 5, 6 dan 7).

Daerah pasang maksimum Pantai Laboya (B1), ketiga daerahnya didominasi oleh pasir sedang (Tabel 5). Berbeda halnya dengan daerah pasang maksimum Pantai Melolo (B5), di daerah pasang maksimum didominasi oleh pasir sedang dan daerah surut maksimum didominasi oleh pasir kasar, sedangkan daerah transisi didominasi oleh pencampuran pasir kasar hingga pasir halus (Tabel 6). Sama halnya dengan yang terdapat di Pantai Waikelo, Sumba (Nugroho \& Putra, 2017) didominasi oleh pasir sedang, daerah surut maksimum didominasi oleh pasir kasar, sedangkan pencampuran pasir halus hingga pasir sangat kasar mendominasi daerah transisi (Tabel 7).

Tabel 5. Persentase besar butir dan penamaan jenis sedimen dari Pantai Laboya, Sumba (B1)

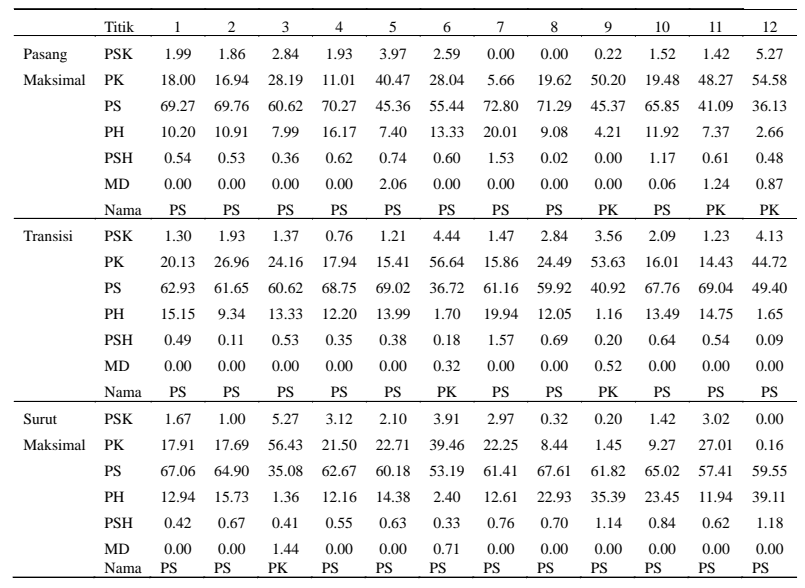

Keterangan: $\mathrm{MD}=$ mud $; \mathrm{PSH}=$ pasir sangat halus; $\mathrm{PH}=$ pasir halus; $\mathrm{PS}$ = pasir sedang; $\mathrm{PK}=$ pasir kasar; $\mathrm{PSK}=$ pasir sangat kasar 
Tabel 6. Persentase besar butir dan penamaan jenis sedimen dari Pantai Melolo, Sumba (B5)

\begin{tabular}{llccccccccc}
\hline & Titik & 1 & 2 & 3 & 4 & 5 & 6 & 7 & 8 & 9 \\
\hline Pasang & PSK & $2.71 \%$ & $4.91 \%$ & $11.74 \%$ & $8.46 \%$ & $3.78 \%$ & $2.02 \%$ & $1.99 \%$ & $1.75 \%$ & $4.77 \%$ \\
Maksimal & PK & $9.58 \%$ & $20.41 \%$ & $27.88 \%$ & $20.09 \%$ & $16.32 \%$ & $15.41 \%$ & $5.97 \%$ & $11.60 \%$ & $19.44 \%$ \\
& PS & $44.97 \%$ & $49.31 \%$ & $37.73 \%$ & $47.30 \%$ & $49.93 \%$ & $51.48 \%$ & $36.69 \%$ & $48.60 \%$ & $46.71 \%$ \\
& PH & $38.99 \%$ & $21.94 \%$ & $17.74 \%$ & $21.53 \%$ & $28.91 \%$ & $29.76 \%$ & $52.15 \%$ & $35.51 \%$ & $26.86 \%$ \\
& PSH & $1.64 \%$ & $1.24 \%$ & $1.35 \%$ & $1.21 \%$ & $1.05 \%$ & $1.32 \%$ & $3.06 \%$ & $1.53 \%$ & $1.60 \%$ \\
& MD & $2.11 \%$ & $2.18 \%$ & $3.57 \%$ & $1.41 \%$ & $0.01 \%$ & $0.01 \%$ & $0.15 \%$ & $1.01 \%$ & $0.63 \%$ \\
& Nama & PS & PS & PS & PS & PS & PS & PH & PS & PH \\
\hline Transisi & PSK & $22.96 \%$ & $10.10 \%$ & $4.79 \%$ & $9.86 \%$ & $11.02 \%$ & $15.76 \%$ & $8.33 \%$ & $21.68 \%$ & $14.08 \%$ \\
& PK & $47.48 \%$ & $37.35 \%$ & $12.30 \%$ & $16.54 \%$ & $27.12 \%$ & $47.82 \%$ & $27.30 \%$ & $32.32 \%$ & $21.40 \%$ \\
& PS & $21.31 \%$ & $37.10 \%$ & $39.43 \%$ & $40.45 \%$ & $40.18 \%$ & $30.16 \%$ & $41.68 \%$ & $30.36 \%$ & $45.40 \%$ \\
& PH & $2.33 \%$ & $8.35 \%$ & $37.23 \%$ & $28.11 \%$ & $18.27 \%$ & $3.50 \%$ & $21.40 \%$ & $13.09 \%$ & $16.30 \%$ \\
& PSH & $0.67 \%$ & $1.18 \%$ & $2.71 \%$ & $4.73 \%$ & $1.27 \%$ & $0.39 \%$ & $1.21 \%$ & $1.07 \%$ & $1.21 \%$ \\
& MD & $5.25 \%$ & $5.91 \%$ & $3.54 \%$ & $0.30 \%$ & $2.14 \%$ & $2.38 \%$ & $0.07 \%$ & $1.48 \%$ & $1.59 \%$ \\
& Nama & PK & PK & PS & PS & PS & PK & PS & PK & PS \\
\hline Surut & PSK & $41.0 \%$ & $29.7 \%$ & $37.8 \%$ & $29.0 \%$ & $9.8 \%$ & $19.1 \%$ & $20.7 \%$ & $12.0 \%$ & $20.0 \%$ \\
Maksimal & PK & $42.1 \%$ & $56.0 \%$ & $47.7 \%$ & $56.4 \%$ & $45.0 \%$ & $55.9 \%$ & $44.8 \%$ & $43.7 \%$ & $55.0 \%$ \\
& PS & $5.1 \%$ & $6.7 \%$ & $6.3 \%$ & $8.9 \%$ & $39.7 \%$ & $21.7 \%$ & $28.2 \%$ & $37.8 \%$ & $20.7 \%$ \\
& PH & $1.4 \%$ & $0.7 \%$ & $0.9 \%$ & $0.8 \%$ & $4.3 \%$ & $1.3 \%$ & $4.0 \%$ & $4.5 \%$ & $3.1 \%$ \\
& PSH & $1.4 \%$ & $0.8 \%$ & $1.0 \%$ & $0.7 \%$ & $0.3 \%$ & $0.3 \%$ & $0.3 \%$ & $0.5 \%$ & $0.6 \%$ \\
& MD & $9.0 \%$ & $6.1 \%$ & $6.3 \%$ & $4.2 \%$ & $0.9 \%$ & $1.7 \%$ & $2.0 \%$ & $1.6 \%$ & $0.7 \%$ \\
& Nama & PK & PK & PK & PK & PK & PK & PK & PK & PK \\
\hline
\end{tabular}

Keterangan: $\mathrm{MD}=m u d ; \mathrm{PSH}=$ pasir sangat halus; $\mathrm{PH}=$ pasir halus; $\mathrm{PS}$ $=$ pasir sedang $; \mathrm{PK}=$ pasir kasar; $\mathrm{PSK}=$ pasir sangat $\mathrm{kasar}$

Tabel 7. Persentase besar butir dan penamaan jenis sedimen dari Pantai Waikelo, Sumba (B7; Nugroho \& Putra, 2017)

\begin{tabular}{|c|c|c|c|c|c|c|c|c|c|c|c|c|c|c|c|c|c|c|c|c|c|c|c|}
\hline & Titik & 1 & 2 & 3 & 4 & 5 & 6 & 7 & 8 & 9 & 10 & 11 & 12 & 13 & 14 & 15 & 16 & 17 & 18 & 19 & 20 & 21 & 22 \\
\hline \multirow[t]{7}{*}{$\begin{array}{l}\text { Pasang } \\
\text { Maksimal }\end{array}$} & SK & 2.20 & 3.20 & 3.90 & 1.60 & 0.00 & 4.70 & 13.30 & 1.50 & 13.91 & 5.62 & 9.06 & 2.97 & 2.61 & 5.39 & 2.29 & 0.84 & 1.68 & 0.00 & 32.76 & 9.02 & 0.00 & 0.00 \\
\hline & PK & 12.23 & 17.07 & 34.62 & 19.10 & 7.74 & 30.45 & 31.33 & 7.67 & 28.46 & 23.99 & 34.62 & 21.02 & 22.67 & 38.10 & 23.76 & 17.40 & 19.71 & 18.12 & 12.52 & 31.90 & 6.28 & 2.89 \\
\hline & PS & 55.08 & 52.83 & 46.57 & 57.08 & 66.92 & 45.46 & 41.78 & 54.36 & 31.52 & 40.56 & 33.53 & 48.77 & 48.62 & 37.42 & 47.96 & 56.08 & 50.71 & 47.83 & 38.44 & 43.73 & 79.66 & 49.24 \\
\hline & $\mathrm{PH}$ & 28.93 & 25.16 & 14.02 & 21.09 & 24.74 & 18.56 & 12.90 & 34.61 & 24.51 & 25.76 & 20.22 & 25.22 & 24.36 & 17.70 & 24.16 & 23.64 & 25.74 & 30.80 & 15.52 & 14.66 & 13.92 & 47.10 \\
\hline & PSH & 1.60 & 1.73 & 0.91 & 1.17 & 0.60 & 0.82 & 0.66 & 1.73 & 1.59 & 2.37 & 2.56 & 1.96 & 1.75 & 1.39 & 1.83 & 1.95 & 2.13 & 3.07 & 0.76 & 0.69 & 0.14 & 0.77 \\
\hline & $\mathrm{MD}$ & 0.00 & 0.00 & 0.00 & 0.00 & 0.00 & 0.00 & 0.00 & 0.10 & 0.00 & 1.70 & 0.00 & 0.05 & 0.00 & 0.00 & 0.00 & 0.08 & 0.00 & 0.15 & 0.00 & 0.00 & 0.00 & 0.00 \\
\hline & Nama & PS & PS & PS & PS & PS & PS & PS & PS & PS & PS & PK & PS & PS & PK & PS & PS & PS & PS & PS & PS & PS & PS \\
\hline \multirow[t]{7}{*}{ Transisi } & PSK & 19.40 & 10.60 & 53.95 & 4.70 & 0.00 & 15.50 & 11.10 & 5.80 & 19.20 & 2.78 & 11.31 & 4.01 & 4.78 & 4.08 & 7.88 & 5.23 & 2.38 & 1.71 & 38.33 & 2.03 & 0.00 & 0.00 \\
\hline & PK & 54.40 & 38.08 & 18.07 & 40.14 & 16.98 & 47.56 & 52.95 & 41.17 & 36.84 & 21.78 & 44.59 & 29.01 & 26.72 & 21.84 & 32.66 & 43.67 & 20.34 & 21.17 & 28.18 & 14.95 & 11.29 & 4.97 \\
\hline & PS & 18.03 & 29.88 & 13.96 & 36.01 & 47.41 & 24.97 & 26.40 & 36.40 & 24.88 & 47.07 & 28.67 & 35.43 & 33.83 & 37.81 & 32.38 & 31.05 & 39.42 & 39.32 & 21.54 & 38.10 & 38.85 & 40.29 \\
\hline & $\mathrm{PH}$ & 7.21 & 19.17 & 12.54 & 17.64 & 33.46 & 11.16 & 8.72 & 15.79 & 17.96 & 26.01 & 14.25 & 28.15 & 31.31 & 33.04 & 24.30 & 17.76 & 34.22 & 34.47 & 11.06 & 41.24 & 46.80 & 53.69 \\
\hline & PSH & 1.00 & 2.27 & 1.47 & 1.53 & 2.15 & 0.85 & 0.80 & 0.82 & 1.11 & 2.28 & 1.18 & 3.31 & 3.28 & 3.14 & 2.79 & 2.30 & 3.48 & 3.24 & 0.89 & 3.49 & 3.07 & 1.04 \\
\hline & MD & 0.00 & 0.00 & 0.00 & 0.00 & 0.00 & 0.00 & 0.00 & 0.00 & 0.00 & 0.10 & 0.00 & 0.10 & 0.09 & 0.09 & 0.00 & 0.00 & 0.16 & 0.09 & 0.00 & 0.20 & 0.00 & 0.00 \\
\hline & Nama & PK & PK & PSK & PK & PS & PS & PK & PK & PK & PS & PK & PS & PS & PS & PK & PK & PS & PS & PSK & PH & PH & PH \\
\hline \multirow[t]{7}{*}{$\begin{array}{l}\text { Surut } \\
\text { Maksimal }\end{array}$} & PSK & 18.70 & 24.50 & 32.70 & 29.00 & 16.80 & 29.20 & 28.86 & 46.90 & 17.96 & 33.03 & 47.76 & 24.66 & 32.28 & 19.06 & 26.24 & 32.03 & 45.17 & 25.82 & 40.10 & 19.24 & 8.51 & 0.50 \\
\hline & PK & 61.23 & 54.63 & 55.35 & 58.02 & 63.56 & 44.73 & 43.34 & 34.17 & 52.88 & 50.84 & 46.21 & 49.30 & 53.61 & 45.71 & 63.77 & 56.01 & 46.08 & 59.89 & 37.17 & 52.28 & 49.99 & 44.93 \\
\hline & PS & 15.84 & 15.24 & 8.31 & 9.73 & 14.87 & 13.03 & 10.08 & 8.24 & 19.95 & 11.90 & 4.98 & 19.41 & 10.98 & 15.01 & 9.06 & 6.94 & 4.90 & 10.04 & 13.66 & 19.69 & 29.19 & 36.84 \\
\hline & PH & 3.93 & 3.22 & 0.94 & 1.75 & 4.21 & 9.50 & 4.65 & 6.57 & 8.12 & 3.76 & 0.96 & 6.16 & 1.72 & 16.42 & 0.88 & 2.66 & 1.04 & 3.73 & 8.37 & 8.05 & 11.39 & 16.45 \\
\hline & PSH & 0.32 & 0.67 & 0.70 & 0.43 & 0.60 & 1.57 & 3.44 & 1.48 & 1.09 & 0.47 & 0.09 & 0.47 & 0.34 & 3.71 & 0.05 & 0.85 & 0.82 & 0.51 & 0.70 & 0.74 & 0.93 & 1.27 \\
\hline & MD & 0.00 & 1.80 & 2.00 & 1.10 & 0.00 & 1.93 & 9.60 & 2.63 & 0.00 & 0.00 & 0.00 & 0.00 & 1.07 & 0.09 & 0.00 & 1.51 & 1.99 & 0.00 & 0.00 & 0.00 & 0.00 & 0.00 \\
\hline & Nama & PK & PK & PK & PK & PK & PK & PK & PK & PK & PK & PK & PK & PK & PK & PK & PK & PK & PK & PSK & PK & PK & PK \\
\hline
\end{tabular}

Keterangan: $\mathrm{MD}=$ = mud PSH = pasir sangat halus; $\mathrm{PH}=$ pasir halus; $\mathrm{PS}=$ pasir sedang; $\mathrm{PK}=$ pasir kasar; $\mathrm{PSK}=$ pasir sangat kasar.

\section{Diagram CM dan Stewart}

Diagram CM dan Stewart digunakan untuk mengetahui mekanisme dan proses pengendapan di sepanjang Pantai Laboya, Melolo dan Waikelo. Endapan pantai diendapkan melalui mekanisme dan proses yang berbeda di masing-masing pantai (Gambar 5 dan 6).
Endapan pantai di ketiga pantai diendapkan dengan mekanisme yang sama, yaitu rolling dan ground suspension (Gambar 5). Pantai Laboya proses pengendapannya hanya dipengaruhi oleh gelombang (Gambar 6a), sedangkan pada Pantai Melolo dan Waikelo (Nugroho \& Putra, 2017) dipengaruhi oleh proses gelombang dan sungai (Gambar $6 \mathrm{~b}$ dan $6 \mathrm{c}$ ). 


\section{Distribusi Nilai-nilai Unsur Kimia}

Berdasarkan analisis XRF, diperoleh unsur-unsur yang dapat menggambarkan asal sumber sedimen yaitu Kalsium (Ca), Strontium (Sr), Kalium (K), dan Besi (Fe) (Gambar 7, Tabel 8). Secara umum, Pantai Laboya memiliki nilai-nilai unsur yang berbeda dengan kedua pantai yang lain. Nilai Ca pada Pantai Laboya (B1) berkisar $60.000-130.000$ ppm, sedangkan pada Pantai Melolo (B5) berkisar $25.000-65.000$ ppm dan nilai pada Pantai Waikelo (B7) berkisar $40.000-70.000$ ppm (Gambar 7; Tabel 8). Nilai Sr di Pantai Laboya (B1) berkisar 500-1500 ppm, di Pantai Melolo (B5) berkisar 1500 - 3500 ppm, sedangkan nilai Sr di Pantai Waikelo (B7) berkisar 2750 - 4000 ppm (Gambar 7; Tabel 8). Nilai K pada Pantai Laboya menunjukkan nilai 2500 6000 ppm, sedangkan pada Pantai Waikelo dan Melolo menujukkan rentang 500 - 1500 ppm (Gambar 7; Tabel 8). Nilai Fe pada Pantai Waikelo dan Melolo menunjukkan nilai yang relatif lebih rendah dibandingkan nilai Fe pada Pantai Laboya, yaitu di bawah 2000 ppm, sedangkan nilai Fe pada Pantai Laboya berkisar antara $6000-18.000 \mathrm{ppm}$. Nilai unsur Titanium (Ti) hanya terekam pada sampel sedimen Pantai Laboya (B1) yaitu berkisar 500 - 1750 ppm (Gambar 8; Tabel 9).

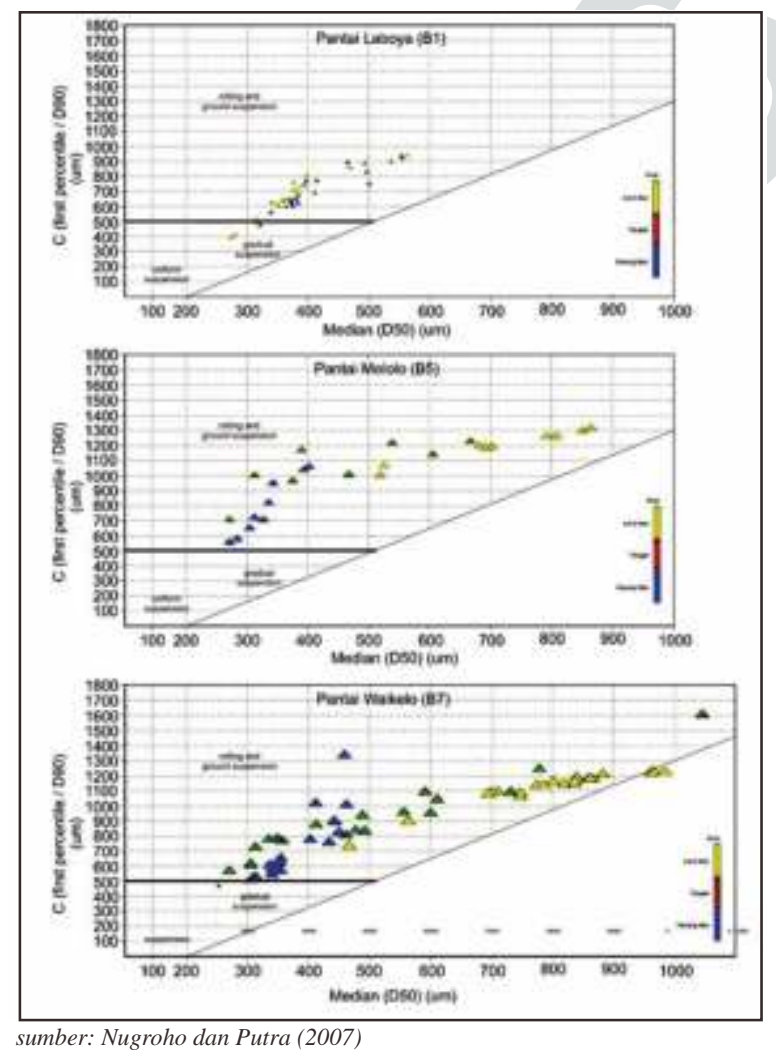

Gambar 5. Diagram CM menggambarkan hubungan median dan nilai persentil pertama (D90; dalam $\mu \mathrm{m}$ ) yang mengindikasikan sebagian besar endapan pantai diendapkan dengan mekanisme rolling dan ground suspension.

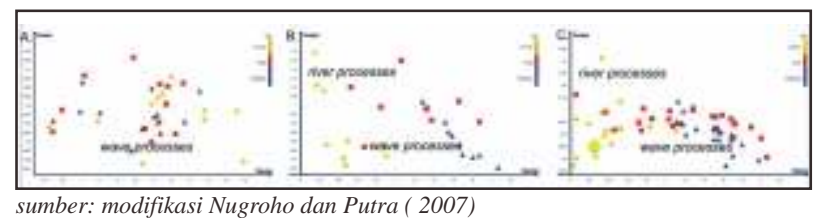

Gambar 6. Diagram Stewart menggambarkan hubungan median dan sortasi yang mengindikasikan sebagian besar endapan pantai dipegaruhi oleh proses gelombang. A. Pantai Laboya (B1), B. Pantai Melolo (B5) dan C. Pantai Waikelo (B7).

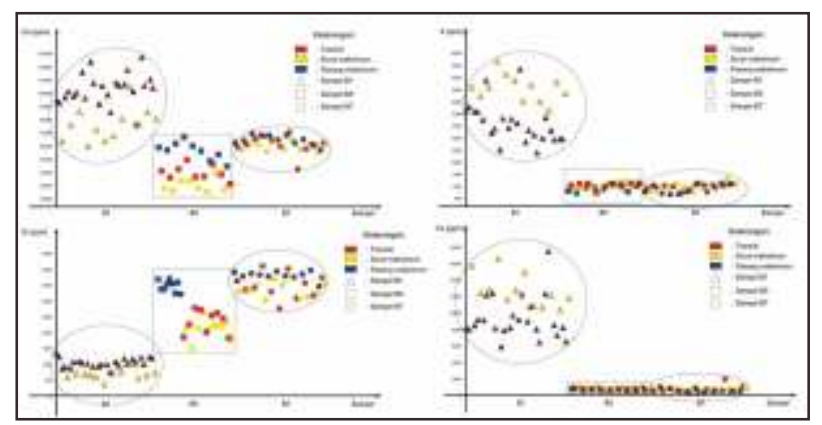

Gambar 7. Analisis unsur-unsur $\mathrm{Ca}, \mathrm{Sr}, \mathrm{K}$ dan $\mathrm{Fe}$ (dalam ppm) pada masing-masing pantai di Pulau Sumba. Masing-masing unsur dapat mengindikasikan batuan sumber asal dan komposisi sedimen.

Tabel 8. Hasil analisis geokimia di Pantai Laboya (B1), Melolo (B5) dan Waikelo (B7), Sumba

\begin{tabular}{|c|c|c|c|c|c|}
\hline No. & Kode Sampel & $\mathrm{Sr}$ & $\mathrm{Fe}$ & $\mathrm{Ca}$ & $\mathbf{K}$ \\
\hline 1 & B1-1A & 1361.33 & 12397.33 & 115939.41 & 3199.15 \\
\hline 2 & B1-1B & 1021.16 & 8123.50 & 96225.63 & 3361.99 \\
\hline 3 & B1-1C & 660.81 & 16580.65 & 59784.07 & 6168.21 \\
\hline 4 & B1-2A & 1225.21 & 5886.37 & 123866.94 & 2508.50 \\
\hline 5 & B1-2B & 924.00 & 7893.81 & 107736.02 & 3793.66 \\
\hline 6 & B1-2C & 577.28 & 11639.09 & 72457.76 & 5635.79 \\
\hline 7 & B1-3A & 938.65 & 8196.08 & 91786.26 & 3411.63 \\
\hline 8 & B1-3B & 984.20 & 9679.86 & 105551.67 & 3780.13 \\
\hline 9 & B1-3C & 370.63 & 12729.04 & 63885.04 & 5368.11 \\
\hline 10 & B1-4A & 990.67 & 9153.15 & 98848.98 & 3612.04 \\
\hline 11 & B1-4B & 741.63 & 12231.57 & 85439.25 & 5841.86 \\
\hline 12 & B1-4C & 711.40 & 14897.52 & 67468.02 & 4521.60 \\
\hline 13 & B1-5A & 1075.30 & 8967.82 & 107789.23 & 2827.04 \\
\hline 14 & B1-5B & 963.70 & 10772.15 & 105683.22 & 3316.55 \\
\hline 15 & B1-5C & 761.79 & 10894.61 & 80329.50 & 5173.47 \\
\hline 16 & B1-6A & 1180.58 & 8019.87 & 106516.26 & 3125.00 \\
\hline 17 & B1-6B & 1012.62 & 6440.01 & 117529.35 & 2389.23 \\
\hline 18 & B1-6C & 1019.78 & 10668.30 & 104630.06 & 4489.18 \\
\hline 19 & B1-7A & 1168.39 & 12299.83 & 101234.29 & 2992.99 \\
\hline 20 & B1-7B & 1053.54 & 17472.55 & 76295.45 & 3830.65 \\
\hline 21 & B1-7C & 550.62 & 12166.42 & 76549.34 & 4125.93 \\
\hline 22 & B1-8A & 1200.15 & 8513.38 & 127132.77 & 3303.07 \\
\hline 23 & B1-8B & 990.88 & 7265.43 & 105733.24 & 2928.71 \\
\hline 24 & B1-8C & 648.52 & 10380.38 & 85479.77 & 5308.10 \\
\hline 25 & B1-9A & 1216.46 & 8220.42 & 110476.18 & 2942.10 \\
\hline 26 & B1-9B & 1191.93 & 6531.85 & 103894.31 & 2954.94 \\
\hline 27 & B1-9C & 726.56 & 11806.68 & 80649.98 & 4819.15 \\
\hline 28 & B1 10A & 854.62 & 8185.25 & 94444.18 & 4124.84 \\
\hline 29 & B1 10B & 917.60 & 7976.67 & 92704.63 & 4271.99 \\
\hline 30 & B1 10C & 592.15 & 15746.27 & 63649.58 & 5108.01 \\
\hline 31 & B1 11A & 872.01 & 8481.75 & 96719.19 & 4076.81 \\
\hline 32 & B1 11B & 1070.18 & 9198.03 & 101193.60 & 4070.80 \\
\hline 33 & B1 11C & 704.56 & 12377.67 & 76062.55 & 4741.55 \\
\hline 34 & B1 12A & 1092.97 & 9131.10 & 97602.03 & 3747.52 \\
\hline 35 & B1 12B & 1034.33 & 12159.23 & 100381.34 & 5378.75 \\
\hline 36 & B1 $12 \mathrm{C}$ & 692.87 & 12780.98 & 86140.84 & 5100.18 \\
\hline 37 & B5-1A & 3676.19 & 752.56 & 58868.54 & 789.92 \\
\hline 38 & B5-1B & 1852.14 & 874.60 & 41000.93 & 1030.92 \\
\hline 39 & B5-1C & 2113.07 & 687.19 & 27650.01 & 910.24 \\
\hline 40 & B5-2A & 3367.23 & 788.15 & 56756.63 & 723.78 \\
\hline 41 & B5-2B & 2257.53 & 598.12 & 35849.24 & 1095.21 \\
\hline
\end{tabular}




\begin{tabular}{|c|c|c|c|c|c|}
\hline 42 & B5-2C & 1503.67 & 919.70 & 26079.67 & 983.97 \\
\hline 43 & B5-3A & 3357.76 & 786.47 & 61761.14 & 949.57 \\
\hline 44 & B5-3B & 2774.50 & 698.45 & 42366.08 & 1106.88 \\
\hline 45 & B5-3C & 2131.24 & 714.21 & 33475.44 & 981.93 \\
\hline 46 & B5-4A & 3510.27 & 823.30 & 66522.77 & 963.68 \\
\hline 47 & B5-4B & 2711.66 & 601.79 & 49457.30 & 720.74 \\
\hline 48 & B5-4C & 2613.28 & 665.41 & 33198.48 & 853.32 \\
\hline 49 & B5-5A & 3686.18 & 628.23 & 59918.47 & 859.16 \\
\hline 50 & B5-5B & 2009.07 & 613.30 & 36556.14 & 981.83 \\
\hline 51 & B5-5C & 2083.11 & 602.82 & 27758.13 & 976.64 \\
\hline 52 & B5-6A & 3547.61 & 723.84 & 56183.09 & 1084.59 \\
\hline 53 & B5-6B & 2532.29 & 681.77 & 36665.55 & 1076.23 \\
\hline 54 & B5-6C & 2207.22 & 596.73 & 25065.67 & 1153.70 \\
\hline 55 & B5-7A & 3246.74 & 746.50 & 48611.02 & 1083.73 \\
\hline 56 & B5-7B & 2608.92 & 524.46 & 46160.96 & 975.23 \\
\hline 57 & B5-7C & 2191.48 & 651.33 & 40032.17 & 1196.14 \\
\hline 58 & B5-8A & 3578.33 & 801.49 & 53381.80 & 764.20 \\
\hline 59 & B5-8B & 2428.76 & 584.60 & 38446.43 & 1100.36 \\
\hline 60 & B5-8C & 2303.23 & 685.82 & 26751.35 & 1139.98 \\
\hline 61 & B5-9A & 3209.70 & 875.74 & 44483.93 & 1016.16 \\
\hline 62 & B5-9B & 1830.83 & 595.87 & 30955.45 & 1122.29 \\
\hline 63 & B5-9C & 1764.88 & 652.14 & 31215.89 & 1041.29 \\
\hline 64 & B7 1A & 3929.35 & 880.10 & 64621.03 & 773.90 \\
\hline 65 & B7 1B & 2757.78 & 437.46 & 59717.78 & 852.36 \\
\hline 66 & B7 1C & 3510.30 & 608.44 & 57918.00 & 747.28 \\
\hline 67 & B7 3A & 3750.57 & 500.52 & 62161.24 & 1031.25 \\
\hline 68 & B7 3B & 3074.63 & 629.01 & 42439.24 & 757.85 \\
\hline 69 & B7 3C & 3083.86 & 588.56 & 57440.59 & 1082.40 \\
\hline 70 & B7 5A & 3841.79 & 553.89 & 65001.04 & 1042.74 \\
\hline 71 & B7 5B & 3567.06 & 1949.72 & 57913.93 & 941.65 \\
\hline 72 & B7 5C & 3127.93 & 674.09 & 59212.71 & 958.08 \\
\hline 73 & B77A & 3965.35 & 541.20 & 61217.90 & 1123.43 \\
\hline 74 & B7 7B & 3173.40 & 569.70 & 60451.13 & 1029.29 \\
\hline 75 & B7 7C & 3261.85 & 593.59 & 55404.50 & 1333.54 \\
\hline 76 & B7 9A & 3457.00 & 496.15 & 56813.24 & 1092.59 \\
\hline 77 & B7 9B & 3739.71 & 1052.77 & 62110.56 & 1096.39 \\
\hline 78 & B7 9C & 3544.90 & 929.76 & 61367.23 & 1079.21 \\
\hline 79 & B7 11A & 3901.26 & 613.99 & 62333.29 & 772.94 \\
\hline 80 & B7 11B & 3629.20 & 565.65 & 58601.78 & 911.99 \\
\hline 81 & B7 11C & 3297.57 & 718.45 & 57817.88 & 791.74 \\
\hline 82 & B7 13A & 3773.29 & 997.93 & 64199.82 & 1034.86 \\
\hline 83 & B7 13B & 3359.32 & 549.62 & 60951.63 & 960.92 \\
\hline 84 & B7 13C & 3314.26 & 732.83 & 62215.08 & 727.07 \\
\hline 85 & B7 15A & 3860.69 & 802.68 & 69198.52 & 715.53 \\
\hline 86 & B7 15B & 3410.63 & 738.44 & 65256.00 & 1027.85 \\
\hline 87 & B7 15C & 3522.82 & 516.97 & 61034.12 & 947.16 \\
\hline 88 & B7 17A & 3824.21 & 574.17 & 68131.36 & 653.69 \\
\hline 89 & B7 17B & 4098.11 & 559.67 & 67609.20 & 985.63 \\
\hline 90 & B7 17C & 3027.37 & 530.02 & 56416.08 & 1088.99 \\
\hline 91 & B7 19A & 3771.60 & 464.33 & 67968.41 & 676.96 \\
\hline 92 & B7 19B & 3292.79 & 435.02 & 64263.75 & 735.75 \\
\hline 93 & B7 19C & 3694.93 & 512.03 & 63511.84 & 998.55 \\
\hline 94 & B7 21A & 3781.49 & 446.47 & 68156.09 & 1076.38 \\
\hline 95 & B7 21B & 4009.43 & 688.23 & 70327.09 & 1126.88 \\
\hline 96 & B7 21C & 3780.87 & 604.47 & 65057.89 & 958.99 \\
\hline
\end{tabular}

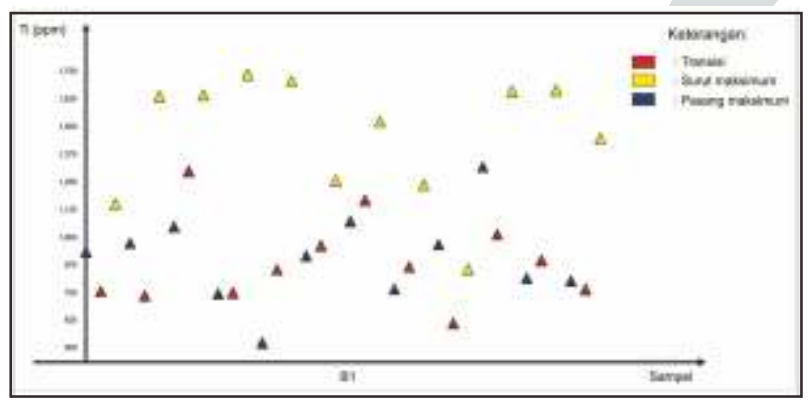

Gambar 8. Kandungan unsur Ti yang hanya ditemukan pada sedimen Pantai Laboya (B1). Hal ini mengindikasikan adanya pengaruh dari batuan gunungapi anggota Formasi Jawila (Tmj).
Tabel 9. Hasil analisis geokimia unsur Ti yang hanya terekam pada sampel B1 (Pantai Laboya)

\begin{tabular}{|c|c|c|}
\hline No. & Kode Sampel & $\mathbf{T i}$ \\
\hline 1 & B1-1A & 740.42 \\
\hline 2 & B1-1B & 744.72 \\
\hline 3 & B1-1C & 1732.41 \\
\hline 4 & B1-2A & 518.81 \\
\hline 5 & B1-2B & 849.20 \\
\hline 6 & B1-2C & 1702.26 \\
\hline 7 & B1-3A & 911.64 \\
\hline 8 & B1-3B & 956.96 \\
\hline 9 & B1-3C & 1251.15 \\
\hline 10 & B1-4A & 1068.59 \\
\hline 11 & B1-4B & 1163.27 \\
\hline 12 & B1-4C & 1519.04 \\
\hline 13 & B1-5A & 761.05 \\
\hline 14 & B1-5B & 861.92 \\
\hline 15 & B1-5C & 1233.47 \\
\hline 16 & B1-6A & 963.57 \\
\hline 17 & B1-6B & 606.90 \\
\hline 18 & B1-6C & 850.62 \\
\hline 19 & B1-7A & 1314.05 \\
\hline 20 & B1-7B & 1008.17 \\
\hline 21 & B1-7C & 1655.24 \\
\hline 22 & B1-8A & 811.65 \\
\hline 23 & B1-8B & 890.51 \\
\hline 24 & B1-8C & 1660.39 \\
\hline 25 & B1-9A & 798.41 \\
\hline 26 & B1-9B & 760.27 \\
\hline 27 & B1-9C & 1443.12 \\
\hline 28 & $\mathrm{~B} 1 \mathrm{10A}$ & 929.47 \\
\hline 29 & B1 10B & 751.65 \\
\hline 30 & B1 10C & 1146.97 \\
\hline 31 & $\mathrm{~B} 111 \mathrm{~A}$ & 968.30 \\
\hline 32 & B1 11B & 730.89 \\
\hline 33 & B1 11C & 1634.34 \\
\hline 34 & B1 12A & 1043.36 \\
\hline 35 & B1 12B & 1294.87 \\
\hline 36 & $\mathrm{~B} 1 \mathrm{12C}$ & 1639.63 \\
\hline
\end{tabular}

Selain itu, masing-masing pantai menunjukkan nilainilai unsur yang berbeda pada setiap segmennya. Pada segmen surut maksimum, nilai $\mathrm{Ca}$ dan $\mathrm{Sr}$ lebih rendah dibandingkan segmen lainnya pada masing-masing pantai (Gambar 7). Sebaliknya, nilai $\mathrm{K}$ dan $\mathrm{Fe}$ menunjukkan yang relatif lebih tinggi pada segmen surut maksimum dibandingkan segmen lainnya. Namun pada Pantai Laboya, rentang nilai Fe dan K tampak lebih lebar dibandingkan pada kedua pantai lainnya (Gambar 7). 


\section{DISKUSI}

Adanya perbedaan karakteristik pada masing-masing pantai baik pada daerah pasang maksimum, transisi maupun surut maksimum disebabkan oleh beberapa faktor. Sumber asal sedimen menjadi salah satu faktor yang menyebabkan perbedaan karakteristik. Pantai Waikelo (B7) dan Melolo (B5) merupakan pantai yang berhadapan dengan Selat Sumba dan berhadapan pulaupulau sekitar (Pulau Flores dan Pulau Sumbawa) sehingga endapan pantai tersebut mendapat pengaruh besar suplai sedimen dari daratan (Tabel 5 dan 6). Sementara itu, pantai Laboya (B1) yang berhubungan langsung dengan Samudra Hindia yang menyebabkan ukuran endapan pantai lebih halus (Tabel 4). Hal yang sama diungkapkan Putra \& Nugroho (2017) yang melakukan penelitian pada ukuran butir sedimen di Selat Sumba dan sebelah selatan dan barat Samudra Hindia, bahwa sedimen yang berhubungan langsung dengan Samudra Hindia memiliki karakter lebih halus dibandingkan yang berada di selat Sumba. Bascom (1951) juga mengemukakan bahwa ada hubungan positif antara distribusi besar butir sedimen dengan energi gelombang. Pantai yang berhadapan langsung dengan Samdra Hindia, Pantai Melolo, akan mendapat pengaruh energi gelombang yang lebih besar dibandingkan yang berhadapan dengan Selat Sumba, sehinga mengakibatkan ukuran butir yang relative lebih kecil. Nugroho \& Putra (2017) menjelaskan bahwa pengendapan endapan Pantai Waikelo dipengaruhi oleh energi pengendapan yang rendah hingga sedang, sehingga diindikasikan bahwa endapan pantai Laboya (B1) diendapkan oleh energi pengendapan yang lebih besar.

Sortasi (pemilahan) butir endapan pantai berkaitan dengan distribusi besar butirnya. Secara umum, sortasi di Pantai Laboya (B1) menunjukkan pemilahan cukup baik (well moderately sorted), sedangkan di Pantai Melolo (B5) dan Waikelo sortasi didominasi oleh sortasi sedang (moderately sorted). Pemilahan yang lebih buruk menunjukkan ukuran butir yang beragam dibandingkan yang terpilah lebih baik. Perbedaan nilai sortasi ini diindikasikan berkaitan dengan kecepatan arus dan arah serta jarak sumber sedimen. Pantai Waikelo (B7) dan Melolo (B5) yang terlindung oleh pulau-pulau di depannya (Pulau Flores dan Sumbawa) menyebabkan arus yang masuk ke pantai relatif lebih kecil karena relatif lebih terlindungi dibandingkan pantai Melolo yang berhadapan langsung dengan Samudra Hindia.
Nilai kurtosis tidak terlalu signifikan menunjukkan perbedaan di masing-masing pantai, meskipun ada beberapa segmen di Pantai Waikelo dan Melolo menunjukkan perbedaan klasifikasi nilai kurtosis. Namun hampir secara keseluruhan menunjukkan nilai kurtosis yang masuk dalam klasifikasi sangat terpancung (very platikurtic). Friedman (1962) mengungkapkan bahwa nilai kurtosis dapat menjelaskan energi pengendapan sedimen, namun nilai kurtosis sedimen pada ketiga pantai di Pulau Sumba sulit untuk menjelaskan kondisi energi pengendapannya. Menurut McClaren \& Bowles (1984) adanya kenaikan energi dalam proses transportasi sedimen dicirikan oleh adanya nilai skewness dari highly negative skewness menjadi simetris. Nilai skewness di ketiga pantai hampir seluruhnya memiliki nilai simetris, sehingga dapat dikatakan bahwa adanya peningkatan energi pengendapan yang terjadi terutama di Pantai Laboya yang berhadapan langsung dengan Samudra Hindia.

Diagram C-M yang dibuat oleh Passega (1964) yang menggambarkan hubungan persentil pertama dan median untuk menunjukkan mekanisme sedimentasi yang terjadi. Secara umum mekanisme sedimentasi yang terjadi dalam proses menggelinding (rolling and ground suspension). Proses mekanisme yang lazim terjadi pada endapan pantai dan muara sungai adalah menggelinding. Diagram Stewart (1958) menggambarkan hubungan antara median dan sortasi yang mengindikasikan adanya proses gelombang dalam pengendapan sedimen di sepanjang pantai (Gambar 6). Ada beberapa segmen pantai yang juga dipengaruhi oleh suplai sedimen dari sungai-sungai besar yang bermuara di pantai, terutama pantai-pantai yang berada di utara Pulau Sumba (Pantai Waikelo dan Melolo).

Sumber dan komposisi sedimen dapat diinterpretasikan berdasarkan analisis geokimia (Tabel 8). Kandungan unsur $\mathrm{Ca}$ dan $\mathrm{Fe}$ yang melimpah pada sampel pantai Laboya (B1) mengindikasikan bahwa komposisi sedimen tersebut banyak terdapat unsur biogenik, karbonat dan sedimen klastik. Sebagaimana yang disebutkan Ritcher et al. (2006) dan Rothwell \& Croudace (2015) bahwa unsur Ca merupakan proksi produksi biogenik, sedangkan unsur Fe merupakan proksi sedimen klastik. Kandungan biogenik yang melimpah pada sedimen Pantai Laboya menunjukkan adanya pengaruh laut yang tinggi. Hal tersebut dikarenakan letak pantai tersebut berbatasan langsung dengan Samudra Indonesia. Kandungan sedimen klastik diindikasikan berasal dari lapukan batuan asal 
dari Formasi Waikabubak (Tmpw) dan Formasi Kananggar (Tmpk). Dalam peta geologi regional (Effendi \& Apandi, 1993) anggota formasi tersebut adalah batugamping, batupasir-napalan, napal pasiran (Gambar 9). Selain itu, kadungan Ti (Tabel 9) yang hanya ditemukan pada sampel pantai Laboya (B1) berhubungan erat dengan batuan asal dari kedua formasi tersebut yaitu batupasir tufan, tuf, dan napal tufan serta dari Formasi Jawila (Tmj) yang berupa batuan gunungapi. Rothwell \& Croudace (2015) menyampaikan bahwa unsur Ti mengindikasikan ada hubungannya dengan material piroklastik. Kandungan $\mathrm{Sr}$ pada sedimen yang ditemukan di ketiga pantai mengindikasikan kelimpahan organisme pembentuk cangkang. Tingginya nilai $\mathrm{Sr}$ pada segmen pasang maksimum, mengindikasikan banyaknya organisme bercangkang yang hidup di zona intertidal seperti moluska dan gastropoda. Kandungan Fe dan K mencirikan suplai sedimen darat. Ketiga pantai menunjukkan nilai Fe dan $\mathrm{K}$ yang tingi berada pada segmen surut maksimum. Hal ini mengindikasikan bahwa sedimen yang berasal dari lapukan batuan asal yang berada di darat kemudian tertransport melalui sungai dan dipengaruhi oleh arus dan mengendap di daerah surut maksimum.

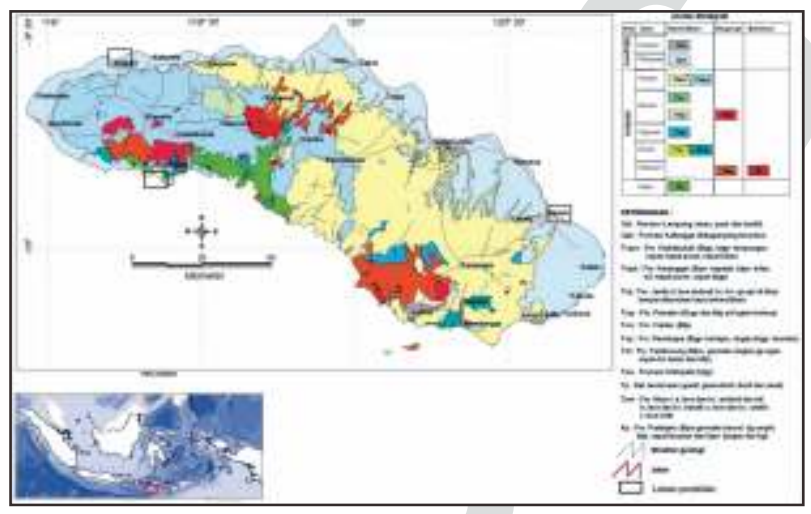

Gambar 9. Peta Geologi regional Pulau Sumba (Effendi \& Apandi, 1993; modifikasi dari Widodo \& Kisman, 2011).

\section{KESIMPULAN}

Karakteristik endapan pantai dapat dibedakan berdasarkan segmen daerahnya yaitu daerah pasang maksimum, transisi dan surut maksimum. Masingmasing pantai di Pulau Sumba memiliki karakteristik distribusi sedimen yang berbeda-beda. Secara umum, pasir sedang - pasir kasar mendominasi sedimen di sepanjang pantai. Endapan Pantai Laboya (B1) memiliki karakteristik yang relatif seragam di ketiga segmen, yaitu pasir sedang dengan sortasi cukup baik. Karakteristik endapan Pantai Melolo (B5) dan Waikelo (B7) relatif sama yang memiliki perbedaan di setiap segmen yaitu pasir sedang - kasar dengan sortasi sedang. Endapan pantai di ketiga pantai tersebut dipengaruhi oleh mekanisme pengendapan mengelinding dan proses gelombang yang membantu proses pengendapan. Suplai sedimen di beberapa segmen pantai juga dipengaruhi oleh sungai. Kandungan unsur-unsur yang terdapat dalam sedimen mengindikasikan batuan asal dan komposisi sedimen. Unsur Ca, Fe dan Ti yang melimpah di Pantai Laboya mengindikasikan sedimen berasal dari lapukan Formasi Tmpw, Tmpk dan Tmj. Kelimpahan unsur Fe dan K pada segmen surut maksimum mengindikasikan adanya pengaruh sungai yang membawa suplai sedimen darat dan terendapkan pada daerah surut maksimum melalui proses gelombang.

\section{UCAPAN TERIMA KASIH}

Penelitian ini merupakan bagian dari Ekspedisi Widya Nusantara (EWIN 2016). Penulis mengucapkan terima kasih kepada Dr. Dirhamsyah, M.A. selaku Kepala Pusat Penelitian Oseanografi dan Dr. Udhi Eko Hernawan selaku koordinator kegiatan EWIN 2016 atas kesempatan yang diberikan dalam mengikuti kegiatan ekspedisi tersebut. Tidak lupa penulis juga mengucapkan terima kasih kepada Nakhoda dan Anak Buah Kapal Baruna Jaya VIII yang telah membantu dalam proses pengambilan data. Ucapan terima kasih juga kami sampaikan untuk Sdr. Singgih Prasteyo Adi Wibowo, AMd. selaku teknisi geologi yang telah banyak membantu selama ekpsedisi berlangsung. Serta para peneliti dan teknisi yang mengikuti kegiatan ekspedisi tersebut atas kerjasamanya selama kegiatan berjalan. Dan penulis juga mengucapkan terima kasih kepada Sdr. Tegar Maulana yang telah membantu dan memberikan saran dan masukan dalam proses penulisan dan pengeditan paper ini.

Tulisan ini dibuat oleh Septriono Hari Nugroho sebagai Kontributor Utama yang menyusun dan memberikan ide dalam penulisan ini, sedangkan Purna Sulastya Putra sebagai kontributor anggota yang memberikan saran dan masukan dan ide tambahan dalam penulisan makalah ini. 


\section{ACUAN}

Anithamary, I., Ramkumar, T. and Venkatramanan, S., 2011. Grain Size Characteristics of the Coleroon Estuary Sediments, Tamilnadu, East Coast of India. Carpathian Journal of Earth and Environmental Sciences 6: 15157.

Angusamy, N.G. and Rajamanickam, V., 2006. Depositional Environment of Sediments along the Southern Coast of Tamil Nadu, India. Oceanologia 48: 87-102.

Angusamy, N.G. and Rajamanickam, V., 2007. Coastal Processes of Central Tamil Nadu, India: Clues from Grainsize Studies. Oceanologia 49: 41-57.

Bascom, W.N., 1951. The Relationship BetweenSand-size and Beach Face Slope. Transactions American Geophysical Union 32: 866-87.

Blott, S.J. and Pye, K., 2001. Gradistat: A Grain Size Distribution and Statistics Package for the Analysis of Unconsolidated Sediments. Earth Surface Processes and Landforms 26: 1237-48. doi:10.1002/esp.261

Brouwer, P., 2003. Theory of XRF: Getting Acquainted with the Principles. PANalytical B.V, Almelo, the Netherlands.

Carranza-Edwards, A., 2001. Grain Size and Sorting in Modern Beach Sands. Journal of Coastal Research, 17(1): 3852.

Effendi, A.C. dan Apandi, T., 1993. Peta Geologi Lembar Waikabubak dan Waingapu, Nusa Tenggara Timur. Pusat Penelitian dan Pengembangan Geologi, Bandung.

Folk, R.L. and Ward, M.C., 1957. Brazos River Bars: A Study in the Significance of Grain Size Parameters. Journal of Sedimentary Petrology 27: 3-27.

Friedman, G.M., 1961. Distinction between Dune, Beach and River Sands from Their Textural Characteristics. Journal of Sedimentary Petrology 31:514-529.

Friedman, G.M., 1962. On Sorting, Sorting Coefficient and the Log Normality of the Grain Size Distribution of Sandstones. Journal of Geology 70: 734-53.

Gosseau, D., 2009. Introduction to XRF Spectroscopy. http://www.user.skynet.Diakses tanggal 21 Oktober 2017.

Irzon, R. 2018. Komposisi Kimia Pasir Pantai di Selatan Kulon Progo dan Implikasi Terhadap Provenance. Jurnal Geologi dan Sumberdaya Mineral 19(1):31-45.

Komar, P.D., 1976. Beach Processes and Sedimentation. Prentice-Hall, Englewood Cliffs, N.Y.429p

Malvarez, G.C., Cooper, J.A.G. and Jackson, D.W.T., 2001. Relationships Between Wave-induced Currents and Sediment Grain Size on a Sandy Tidal-Flat. Journal of Sedimentary Research 71: 705-712. doi:10.1306/2dc40961-0e47-11d7-8643000102c1865d.

McClaren, P. and Bowles, D., 1984. The Effects of Sediment Transport on Grain-Size Distributions. Journal of Sedimentary Petrology 55 (4): 457-470.

Nordstrom, K.F., 1977. The use of grain size statistics to distinguish between high- and moderate energy beach environments. Journal of Sedimentary Petrology 47(3): 1287-1294.

Nugroho, S.H., 2013. Kondisi Geomorfologi, Sedimen Permukaan dan Aktivitas Manusia di Kawasan Wisata Bahari di Desa Morella dan Negeri Lima, Ambon. Oseanologi dan Limnologi di Indonesia 39: 263-76.

Nugroho, S.H dan Basit, A., 2014. Sebaran Sedimen Berdasarkan Analisis Ukuran Butir di Teluk Weda, Maluku Utara. Jurnal Ilmu dan Teknologi Kelautan Tropis 6 (1): 229-240.

Nugroho, S.H. dan Putra, P.S., 2017. Spatial Distribution of Grain Size and Depositional Process in Tidal Area along Waikelo Beach, Sumba. Marine Georesources and Geotechnology 36(3): 299-307. DOI: 10.1080/1064119X.2017.1312649.

Passega, R., 1964. Grain Size Repersentation by CM Pattern as a Geological Tool. Journal of Sedimentary Petrology 34: 830-847. 
Passega, R. and Byramjee, R., 1969. Grain-Size Image of Clastic Deposits. Sedimentology 13: $233-52$. doi:10.1111/j.1365-3091.1969.tb00171.x.

Putra, P.S. dan Nugroho, S.H., 2017. Distribusi Sedimen Permukaan Dasar Laut Perairan Sumba, Nusa Tenggara Timur. Oseanologi dan Limnologi di Indonesia 2(3): 49-6.

Ramamohanarao, T., Sairam, K., Venkateswararao, Y., Nagamalleswararao, B. and Viswanath, K., 2003. Sedimentological Characteristics and Depositional Environment of Upper Gondwana Rocks in the Chintalapudi Sub-Basin of the Godavari Valley, Andhra Pradesh, India. Journal of Asian Earth Sciences 21: 691-703. doi:10.1016/S1367-9120(02)00139-6.

Ramanathan, A.L., Rajkumar, K., Majumdar, J., Singh, G., Behera, P.N., Santra, S.C., and Chidambaram, S., 2009. Textural Characteristics of the Surface Sediments of a Tropical Mangrove Sundarban Ecosystem India. Indian Journal of Marine Sciences 38: 397-40. Retrived from http://hdl.handle.net/123456789/7075.

Rajganapathi, V.C., Jitheshkumar, N., Sundararajan, M., Bhat, K.H. and Velusamy, S., 2012. Grain Size Analysis and Characterization of Sedimentary Environment along Thiruchendur Coast, Tamilnadu, India. Arab Journal Geosciences. doi:10.1007/s12517-012-0709-0

Rao, P.S., Ramaswamy, V and Thwin, S., 2005. Sediment Texture, Distribution and Transport on the Ayeyarwady Continental Shelf, Andaman Sea. Marine Geology 216: 239-47. doi:10.1016/j.margeo.2005.02.01

Rothwell, R.G. and Croudace, I.W., 2015. Twenty Years of XRF Core Scanning Marine Sediments: What Do Geochemical Proxies Tell Us? In Croudace, I. W. and Rothwell, R. G. (eds). Micro-XRF Studies of Sediment Cores: Applications of a Non-Destructive Tool for the Environmental Sciences. Development in Paleoenvironmental Research 17. Springer, Southampton: pp. 25-102.

Richter, T. O., van der Gaast, S., Koster, B., Vaars, A., Gieles, R., de Stigter,H.C, de Haas, H. and van Weering, T.C.E., 2006. The Avaatech XRF Core Scanner: Technical Description and Applications to NE Atlantic Sediments. In G. Rothwell (ed). New Techniques in Sediment Core Analysis. Spec. Publ. Geol. Soc. 267: 39-50.

Stewart, H.B., 1958. Sedimentary Reflection on Depositional Environment, in San Mignellagoon, Baju California, Mexico. AAPG Bull. 42: 2567-2618.

Suresh, G.M., Solai, A., Chandrasekaran, K., and Rammohan, V., 2008. Sediment Characteristics and Heavy Mineral Distribution in Tamiraparani Estuary and Off Tuticorin, Tamil Nadu - SEM Studies. e-Journal of Earth Sciences India 1:102-18.

Visher, G. S., 1969. Grain Size Distribution and Depositional Process. Journal of Sedimentary Research 39:1074-106.

Widodo, W. dan Kisman. 2011. Prospeksi Mineral Logam Di Kabupaten Sumba Timur Provinsi Nusa Tenggara Timur. Prosiding Hasil Kegiatan Pusat Sumber Daya Geologi Tahun 2011. II.26

Zuraida, R., Gerhaneu, N.Y., dan Sulistyawan, I.H. 2017. Karakteristik Sedimen Pantai dan Dasar Laut di Teluk Papela, Kabupaten Rote, Provinsi Nusa Tenggara Timur. Jurnal Geologi Kelautan 15(2): 81-94. 